\title{
Hubungan Pemakaian Alat Kontrasepsi Dalam Rahim (AKDR) Non Hormonal dengan Kejadian Vaginitis
}

\author{
Eka Mega Sari ${ }^{1}$, Shinta Prawitasari ${ }^{2}$, Ahsanudin Attamimi ${ }^{3}$ \\ ${ }^{1,2,3}$ Departemen Obstetri dan Ginekologi, Fakultas Kedokteran-Kesehatan Masyarakat dan Keperawatan, UGM \\ Korespondensi: ekamegasari@gmail.com
}

Submisi:10 Oktober 2018; Revisi: 18 Desember 2018; Penerimaan: 20 Desember 2018

\begin{abstract}
ABSTRAK
Background: Colonies of microorganism in reproductive normal women vaginal is influenced by several factors. Changes in the composition of these factors cause of some problems such as infection and inflammation. The use of intrauterine devices could be expected to lead to vaginitis.

Objective: To determine whether the use of intrauterine device increase the incidence of vaginitis, either by Bacterial Vaginosis (BV), Vulvovaginal Candidiasis (VVC), and Trichomonas Vaginalis (TV) .

Method: Cross Sectional Study on the differences incidence of vaginitis in intrauterine device user and hormonal user. Result and Discussion: At the intrauterine devices and hormonal contraception users, there are significant difference incidence of BV (OR 10,11;95\% Cl 1,80-56,78); $p=0,009$ ( $p<0,05)$ dan VVC (OR 29,78 (1,64-2540,69); $p=0,022(p<0,05)$, but not TV (OR 3,68;95\% Cl 0,11-117,63); $p=0,460$ ( $p>0,05)$.

Conclusions: The use of an intrauterine device increase the incidence BV and VVC but not TV.
\end{abstract}

Keywords: Intrauterine Device; Hormonal Contraception; Vaginitis

\begin{abstract}
ABSTRAK
Latar Belakang: Koloni mikroorganisme pada vagina normal wanita usia produktif dipengaruhi oleh beberapa faktor. Perubahan komposisi faktor tersebut dapat menyebabkan beberapa masalah seperti infeksi dan peradangan. Penggunaan alat kontrasepsi dalam rahim diduga dapat memicu terjadinya vaginitis.

Tujuan: Untuk mengetahui apakah penggunaan alat kontrasepsi dalam rahim meningkatkan kejadian vaginitis, baik oleh karena Vaginosis Bakteri (VB), Candidiasis Vulvovagina (CVV), maupun Trichomonas Vaginalis (TV).

Metode: Penelitian Cross Sectional Study mengenai perbedaan insidensi vaginitis pada wanita akseptor alat kontrasepsi dalam rahim dengan akseptor hormonal

Hasil dan Pembahasan: Pada akseptor alat kontrasepsi dalam rahim dan hormonal, didapatkan perbedaan signifikan kejadian vaginitis yang disebabkan VB (OR 10,11;95\% Cl 1,80-56,78); $p=0,009(p<0,05)$ dan CVV $(O R 29,78(1,64-2540,69)$; $p=0,022(p<0,05)$, tetapi tidak pada TV (OR 3,68;95\% Cl 0,11-117,63); $p=0,460(p>0,05)$.

Kesimpulan: Kejadian VB dan CVV lebih banyak dijumpai pada pengguna AKDR non hormonal tetapi tidak oleh TV.
\end{abstract}

Kata Kunci: Alat Kontrasepsi Dalam Rahim; AKDR; Kontrasepsi Hormonal; Vaginitis 


\section{PENDAHULUAN}

Banyak spesies aerobik dan fakultatif-obligat anaerobik dapat hidup pada vagina normal seorang wanita usia reproduktif. Pada kondisi tersebut, spesies anaerob sepuluh kali lebih banyak didapatkan bila dibandingkan dengan spesies aerob. Alasan mengapa bakteri tersebut berkoloni masih belum jelas. Bakteri dapat bersimbiosis dengan inangnya dan membentuk lingkungan mikro yang bervariasi. ${ }^{1,2}$

Beberapa faktor bertanggung jawab terhadap variasi dari flora vagina pada wanita yang aktif secara seksual. Faktor ini menyebabkan beberapa masalah dengan skala luas, mulai dari discharge vagina yang asimptomatik hingga infeksi pelvis yang berat. Vaginosis Bakteri(VB) merupakan masalah yang dianggap sebagai gangguan tersering pada vagina yang menyerang wanita dan dikarakterisasikan sebagai pertumbuhan yang berlebihan dari beberapa bakteri anaerob dan mikroaerofilik dan menurunnya prevalensi Lactobacillus $s p$ karena perubahan morfotipe bakteri vagina:. ${ }^{1,3}$ Agen penyebab lain dari vaginitis adalah Trikomoniasis, Candidiasis, dan infeksi bakteri lain. Faktor risiko penyebabnya antara lain perilaku yang tidak higienis, perawatan yang tidak tepat selama menstruasi, perilaku berganti ganti pasangan, dan penggunaan kontrasepsi. ${ }^{4,5}$

Tabel 1. Dua puluh pola penyakit rawat jalan di poliklinik Obstetri dan Ginekologi RSUP DR Sardjito tahun 2014

\begin{tabular}{|c|c|c|}
\hline & Diagnosis & Jumlah kunjungan \\
\hline 1 & Kanker serviks & 2089 \\
\hline 2 & Kanker ovarium & 1592 \\
\hline 3 & Kanker endometrium & 606 \\
\hline 4 & Kista ovarium & 604 \\
\hline 5 & Kanker endocerviks & 406 \\
\hline 6 & Kista ovarium lainnya & 392 \\
\hline 7 & Mioma uteri & 290 \\
\hline 8 & Endometriosis & 226 \\
\hline 9 & Kista coklat & 218 \\
\hline 10 & Penyakit vagina noninflamasi lainnya & 177 \\
\hline 11 & Penyakit radang serviks uteri & 126 \\
\hline 12 & Prolapse uterovaginal & 124 \\
\hline 13 & Vaginitis akut & 124 \\
\hline 14 & Kanker korpus uteri & 120 \\
\hline 15 & Mola hidatidosa & 118 \\
\hline 16 & Sistokel & 111 \\
\hline 17 & Endometriosis uterus & 103 \\
\hline 18 & Mioma uteri submukosa & 97 \\
\hline 19 & Rektokel & 92 \\
\hline 20 & Seksio sesarea & 86 \\
\hline
\end{tabular}

(Sumber: Rekam Medis RSUP DR Sardjito) 
Dari data diatas vaginitis menempati urutan ke 13 dari 20 besar penyakit di RSUP DR Sardjito dari bulan Januari sampai dengan Desember tahun 2014, sedangkan penyakit vagina noninflamasi menempati urutan ke 10.

Alat Kontrasepsi Dalam Rahim (AKDR), merupakan salah satu metode kontrasepsi yang paling banyak digunakan di dunia. Secara global, $14,3 \%$ wanita usia 15-49 tahun yang telah menikah memilih menggunakan AKDR sebagai metode kontrasepsinya walaupun presentase pemakaian AKDR berbeda-beda menurut region dan benua. Kisaran pemakaian AKDR adalah sekitar 1,8\% di Oceania hingga $27 \%$ di Asia. Secara geografis, $80 \%$ pengguna AKDR berasa di Asia, dengan sekitar duapertiga nya (64\%) berada di Cina. ${ }^{6}$

Di seluruh dunia, wanita pengguna kontrasepsi hanya sekitar $62,7 \%$, dimana negara maju lebih banyak penggunanya $(72,4 \%)$ dibanding negara berkembang (61,2\%). Tetapi pengguna kontrasepsi AKDR lebih banyak pada Negara berkembang $(24,7 \%)$ dibandingkan Negara maju (12,7\%). Tingkat penggunaan AKDR berurutan yaitu Asia (27\%), diikuti Eropa (17.1\%), Afrika (15.4\%), Amerika Latin (9.6\%), Amerika Utara (6.1\%) dan Oceania 1.8\%). ${ }^{6}$

Di Asia, penggunaan AKDR juga mempunyai tingkat variasi yang ekstrim. Dari mulai Cina, Korea Selatan, dan Vietnam yang mempunyai tingkat pemakaian AKDR 41\% - 44\%, hingga beberapa Negara Asia lain yang hanya mempunyai tingkat penggunaan sekitar kurang dari 2\%. Data dari Chinese national surveys yang dihimpun oleh National Population and Family Planning Committee telah memperlihatkan bahwa pada wanita usia 15-49 tahun yang telah menikah, terjadi peningkaan penggunaan AKDR dari 42,1\% pada 1988 menjadi $48 \%$ pada $2006^{6}$

Data diatas tersebut sangat bertolak belakang dengan yang terjadi di Amerika Serikat. Penggunaan AKDR di Amerika Serika sangat sedikit bila dibandingkan dengan penggunaan di beberapa Negara berkembang lainnya. Sekitar setengah dari kehamilan yang terjadi di Amerika Serikat merupakan kehamilan yang tidak diinginkan, dan $48 \%$ kehamilan tersebut terjadi pada wanita yang telah memakai kontrasepsi, sedangkan AKDR telah terbukti sebagai metode kontrasepsi yang aman, efektifitas tinggi, dan kontrasepsi jangka lama yang banyak diterima oleh banyakwanita. Beberapa data telah menunjukkan bahwa AKDR 20 kali lebih efektif bila dibandingkan dengan metode kontrasepsi hormonal lain yang lebih populer di Amerika seperti pil. ${ }^{7}$

Beberapa penelitian telah menemukan kejadian VB yang lebih tinggi pada pemakaian AKDR dibandingkan dengan pemakaian kontrasepsi lainnya. Pada sebuah studi di Kanada, dari 70 wanita pengguna AKDR, setelah dilakukan tes ditemukan 5 (7\%) menderita VB. Hanya 1 dari 5 wanita tersebut yang mempunyai keluhan sehingga akhirnya diterapi dengan metronidazole. ${ }^{8}$

\section{METODE}

Penelitian ini merupakan penelitian analitik observasional cross sectional study mengenai perbedaan insidensi vaginitis pada wanita akseptor AKDR non Hormonal dengan wanita akseptor KB Hormonal.

Tempat penelitian ini berlangsung di Puskesmas Jejaring RSUP DR Sardjito yaitu Puskesmas Jetis. Waktu penelitian dimulai pada bulan Juli 2016 sampai dengan Nopember 2016.

Populasi target pada penelitian ini adalah akseptor AKDR non hormonal dan kontrasepsi hormonal. Populasi terjangkau adalah akseptor KB AKDR non hormonal dan kontrasepsi hormonal di poliklinik KB Puskesmas Jetis Yogyakarta pada bulan Juli 2016 sampai Nopember 2016. Teknik mendapatkan sampel adalah dengan pemilihan tidak berdasarkan peluang yaitu consecutive sampling dengan cara mencari penderita yang memenuhi kriteria inklusi dan eksklusi sampai dipenuhi jumlah sampel yang diperlukan.

Kriteria inklusi penelitian ini adalah: wanita akseptor AKDR non hormonal lebih dari 1 tahun, wanita akseptor kontrasepsi hormonal lebih dari 4 bulan, usia subur 18-48 tahun, bersedia ikut dalam penelitian ini. Kriteria eksklusi penelitian ini adalah: pasien yang hamil, belum menikah, menderita diabetes mellitus, terdapat gangguan immunocompromised, menderita servisitis, menopause.

Sampel penelitian adalah akseptor KB AKDR non hormonal dan kontrasepsi hormonal di poliklinik KB Puskesmas Jetis Yogyakarta di mulai setelah ethical approval diterbitkan sampai dengan terpenuhinya jumlah sampel yang memenuhi kriteria inklusi dan eksklusi. Jumlah sampel didapatkan paling banyak pada TV yaitu 39 per grup. 


\section{HASIL DAN PEMBAHASAN}

Penelitian ini dilakukan di poliklinik KB Puskesmas Jetis Kodya Yogyakarta selama bulan Juli sampai dengan Nopember 2016. Jumlah sampel penelitian sebanyak 68 pasien yang dibagi menjadi dua kelompok yaitu 34 pasien yang merupakan akseptor AKDR non hormonal dan 34 pasien yang merupakan akseptor kontrasepsi hormonal. Karakteristik subjek penelitian disajikan pada tabel berikut:

Tabel 2. Karakteristik Subjek Penelitian

\begin{tabular}{llcrrrrr}
\hline & & \multicolumn{2}{c}{ AKDR } & \multicolumn{3}{c}{ Hormonal } & \\
\hline Karakteristik & & $\mathrm{N}$ & $\%$ & $\mathrm{n}$ & $\%$ & $\mathrm{n}$ & $\%$ \\
\hline Usia & $<20$ dan $>35$ & 18 & 52,9 & 20 & 58,8 & 38 & 55,9 \\
& $20-35$ & 16 & 47,1 & 14 & 41,2 & 30 & 44,1 \\
Paritas & Multigravida & 24 & 70,6 & 22 & 64,7 & 46 & 67,6 \\
& Primigravida & 10 & 29,4 & 12 & 35,3 & 22 & 32,4 \\
Pendidikan & Rendah & 6 & 17,6 & 19 & 55,9 & 25 & 36,8 \\
& Tinggi & 28 & 82,4 & 15 & 44,1 & 43 & 63,2 \\
& Bekerja & 16 & 47,1 & 15 & 44,1 & 31 & 45,6 \\
\end{tabular}

Pada karakteristik subjek diatas dapat dilihat ada kelompok usia $<20$ dan $>35$ th tahun terdapat 38 kasus $(55,9 \%)$, sedangkan untuk kelompok usia 20-35 tahun terdapat 30 kasus $(44,1 \%)$. Untuk kelompok paritas, terdapat 22 kasus $(32,4 \%)$ pada primigravida dan 46 kasus $(67,6 \%)$ pada multigravida. Berdasarkan tingkat pendidikan, sebagian besar sampel berpendidikan tinggi yaitu sebanyak 43 kasus $(63,2 \%)$ dan 25 kasus $(36,8 \%)$ berpendidikan rendah. Pekerjaan terdapat 31 kasus $(45,6 \%)$ wanita yang bekerja dan 37 kasus $(54,4 \%)$ wanita tidak bekerja.

Tabel 3. Analisis bivariat hubungan metode kontrasepsi dengan Vaginosis Bakteri

\begin{tabular}{|c|c|c|c|c|c|c|}
\hline \multirow{3}{*}{ Metode KB } & \multicolumn{4}{|c|}{ Vaginosis Bakteri } & \multirow{3}{*}{$\mathrm{p}$} & \multirow{3}{*}{ OR (IK 95\%) } \\
\hline & \multicolumn{2}{|c|}{ Ya } & \multicolumn{2}{|c|}{ Tidak } & & \\
\hline & $\mathrm{n}$ & $\%$ & $\mathrm{~N}$ & $\%$ & & \\
\hline AKDR & 29 & 58,0 & 5 & 27,8 & $0,028 *$ & $3,6(1,11-11,62)$ \\
\hline Hormonal & 21 & 42,0 & 13 & 72,2 & & \\
\hline Total & 50 & 100,0 & 18 & 100,0 & & \\
\hline
\end{tabular}

*signifikan

Pada karakteristik subjek diatas dapat dilihat ada kelompok usia $<20$ dan $>35$ th tahun terdapat 38 kasus $(55,9 \%)$, sedangkan untuk kelompok usia 20-35 tahun terdapat 30 kasus $(44,1 \%)$. Untuk kelompok paritas, terdapat 22 kasus $(32,4 \%)$ pada primigravida dan 46 kasus (67,6\%) pada multigravida. Berdasarkan tingkat pendidikan, sebagian besar sampel berpendidikan tinggi yaitu sebanyak 43 kasus $(63,2 \%)$ dan 25 kasus $(36,8 \%)$ berpendidikan rendah. Pekerjaan terdapat 31 kasus $(45,6 \%)$ wanita yang bekerja dan 37 kasus $(54,4 \%)$ wanita tidak bekerja. 
Tabel 4. Analisis bivariat hubungan metode kontrasepsi dengan Candidiasis Vulvovagina

\begin{tabular}{|c|c|c|c|c|c|c|}
\hline \multirow{3}{*}{ Metode KB } & \multicolumn{4}{|c|}{ Candidiasis Vulvovagina } & \multirow{3}{*}{$\mathrm{p}$} & \multirow{3}{*}{ OR (IK 95\%) } \\
\hline & \multicolumn{2}{|c|}{ Ya } & \multicolumn{2}{|c|}{ Tidak } & & \\
\hline & $\mathrm{n}$ & $\%$ & $\mathrm{n}$ & $\%$ & & \\
\hline AKDR & 9 & 90,0 & 25 & 43,1 & $0,006^{*}$ & $11,9(1,41-100,0)$ \\
\hline Hormonal & 1 & 10,0 & 33 & 56,9 & & \\
\hline Total & 10 & 100,0 & 58 & 100,0 & & \\
\hline
\end{tabular}

*signifikan

Pada analisis chi-square menunjukkan ada pengaruh bermakna penggunaan AKDR non hormonal terhadap CVV dengan nilai (OR 11,9; 95\% CI 1,41-100,0). Hal ini menunjukkan akseptor AKDR non hormonal berpeluang mengalami CVV 11,9 kali dibandingkan kontrasepsi hormonal serta terdapat perbedaan bermakna secara statistik dengan nilai $p=0,006(p<0,05)$.

Tabel 5. Analisis bivariat hubungan metode kontrasepsi Trichomonas Vaginalis

\begin{tabular}{|c|c|c|c|c|c|c|}
\hline \multirow{3}{*}{ Metode KB } & \multicolumn{4}{|c|}{ Trichomonas Vaginalis } & \multirow{3}{*}{$\mathrm{p}$} & \multirow{3}{*}{ OR (IK 95\%) } \\
\hline & \multicolumn{2}{|c|}{ Ya } & \multicolumn{2}{|c|}{ Tidak } & & \\
\hline & $\mathrm{n}$ & $\%$ & $\mathrm{n}$ & $\%$ & & \\
\hline AKDR & 2 & 66,7 & 32 & 49,2 & 1,000 & $2,06(0,18-23,89)$ \\
\hline Hormonal & 1 & 33,3 & 33 & 50,8 & & \\
\hline Total & 3 & 100,0 & 65 & 100,0 & & \\
\hline
\end{tabular}

Pada analisis Fisher's Exact menunjukkan secara statistik tidak ada hubungan bermakna penggunaan AKDR non hormonal terhadap TV dengan nilai $p=1,000(p>0,05)$, akan tetapi AKDR non hormonal bermakna secara klinis sebagai penyebab TV(OR 2,06; 95\% CI 0,18-23,89).

Tabel 6. Analisis bivariat hubungan variabel pengganggu dengan Vaginosis Bakteri

\begin{tabular}{|c|c|c|c|c|c|c|c|}
\hline \multirow{3}{*}{ Variabel } & & \multicolumn{4}{|c|}{ Vaginosis Bakteri } & \multirow{3}{*}{$p$} & \multirow{3}{*}{ OR (Cl 95\%) } \\
\hline & & \multicolumn{2}{|c|}{ Ya } & \multicolumn{2}{|c|}{ Tidak } & & \\
\hline & & $\mathrm{n}$ & $\%$ & $\mathrm{n}$ & $\%$ & & \\
\hline \multirow[t]{2}{*}{ Usia } & $<20 />35$ & 27 & 54 & 11 & 61,1 & 0,602 & $0,75(0,25-2,24)$ \\
\hline & $20-35$ & 23 & 46 & 7 & 38,9 & & \\
\hline \multirow[t]{2}{*}{ Paritas } & Multigravida & 35 & 70 & 11 & 61,1 & 0,489 & $1,49(0,48-4,57)$ \\
\hline & Primigravida & 15 & 30 & 7 & 38,9 & & \\
\hline \multirow[t]{2}{*}{ Pendidikan } & Rendah & 17 & 34 & 8 & 44,4 & 0,431 & $0,64(0,22-1,93)$ \\
\hline & Tinggi & 33 & 66 & 10 & 55,6 & & \\
\hline \multirow[t]{2}{*}{ Pekerjaan } & Ya & 25 & 50 & 6 & 33,3 & 0,223 & $2,00(0,65-6,17)$ \\
\hline & Tidak & 25 & 50 & 12 & 66,7 & & \\
\hline \multirow[t]{2}{*}{ Antibiotika } & Ya & 2 & 4,0 & 1 & 5,6 & 1,000 & $0,71(0,06-8,32)$ \\
\hline & Tidak & 48 & 96,0 & 17 & 94,4 & & \\
\hline
\end{tabular}




\begin{tabular}{llcccccc} 
Multipartner & Ya & 2 & 4,0 & 1 & 5,6 & 1,000 & $0,71(0,06-8,32)$ \\
& Tidak & 48 & 96,0 & 17 & 94,4 & & \\
Higiene buruk & Ya & 1 & 2,0 & 1 & 5,6 & 0,462 & $0,35(0,02-5,86)$ \\
& Tidak & 49 & 98,0 & 17 & 94,4 & & \\
\multirow{3}{*}{ Bilas vagina } & Ya & 7 & 14,0 & 4 & 22,2 & 0,464 & $0,57(0,15-2,24)$ \\
& Tidak & 43 & 86,0 & 14 & 77,8 & & \\
\hline
\end{tabular}

Pada uji Fisher's Exact diatas diketahui bahwa tidak terdapat hubungan secara statistik antara usia, paritas, pendidikan, pekerjaan, mengkonsumsi/ menggunakan antibiotik, multipartner, hiegiene buruk, bilas vagina terhadap kejadian VB $p>0,05$, sementara itu pekerjaan didapatkan bermakna secara secara klinis yaitu 2 kali lipat mempengaruhi VB (OR 2,00; 95\% CI 0,65-6,17).

Tabel 7. Analisis bivariat hubungan variabel pengganggu dengan Candidiasis Vulvovagina

\begin{tabular}{|c|c|c|c|c|c|c|c|}
\hline \multirow{3}{*}{ Variabel } & & \multicolumn{4}{|c|}{ Candidiasis Vulvovagina } & \multirow{3}{*}{$\mathrm{p}$} & \multirow{3}{*}{ OR (Cl 95\%) } \\
\hline & & \multicolumn{2}{|c|}{ Ya } & \multicolumn{2}{|c|}{ Tidak } & & \\
\hline & & $\mathrm{N}$ & $\%$ & $\mathrm{~N}$ & $\%$ & & \\
\hline \multirow[t]{3}{*}{ Usia } & $<20 />35$ & 3 & 30 & 35 & 60,3 & 0,094 & $0,28(0,07-1,20)$ \\
\hline & $20-35$ & 7 & 70 & & 39,7 & & \\
\hline & & & & 23 & & & \\
\hline \multirow[t]{3}{*}{ Paritas } & Multigravida & 5 & 50 & & 70,7 & 0,274 & $0,42(0,11-1,62)$ \\
\hline & & & & 41 & & & \\
\hline & Primigravida & 5 & 50 & 17 & 29,3 & & \\
\hline \multirow[t]{2}{*}{ Pendidikan } & Rendah & 1 & 10 & 24 & 41,4 & 0,079 & $0,16(0,02-1,33)$ \\
\hline & Tinggi & 9 & 90 & 34 & 58,6 & & \\
\hline \multirow[t]{2}{*}{ Pekerjaan } & $\mathrm{Ya}$ & 5 & 50 & 6 & 44,8 & 1,000 & $1,23(0,32-4,72)$ \\
\hline & Tidak & 5 & 50 & 32 & 55,2 & & \\
\hline \multirow[t]{2}{*}{ Antibiotika } & $\mathrm{Ya}$ & 1 & 10,0 & 2 & 3,4 & 0,384 & $3,11(0,26-37,96)$ \\
\hline & Tidak & 9 & 90,0 & 56 & 96,6 & & \\
\hline \multirow[t]{2}{*}{ Multipartner } & $\mathrm{Ya}$ & 1 & 10,0 & 2 & 3,4 & 0,384 & $3,11(0,26-37,96)$ \\
\hline & Tidak & 9 & 90,0 & 56 & 96,6 & & \\
\hline \multirow{2}{*}{$\begin{array}{l}\text { Higiene } \\
\text { buruk }\end{array}$} & $\mathrm{Ya}$ & 1 & 10,0 & 1 & 1,7 & 0,274 & $6,33(0,36-110,5)$ \\
\hline & Tidak & 9 & 90,0 & 57 & 98,3 & & \\
\hline \multirow[t]{2}{*}{ Bilas vagina } & $\mathrm{Ya}$ & 2 & 20,0 & 9 & 15,5 & 0,660 & $1,36(0,25-7,49)$ \\
\hline & Tidak & 8 & 80,0 & 49 & 84,5 & & \\
\hline
\end{tabular}

Dari tabel di atas diketahui bahwa tidak terdapat hubungan bermakna secara statistik antara usia, paritas, pendidikan, pekerjaan, mengkonsumsi/ menggunakan antibiotik, multipartner, higiene yang buruk, bilas vagina terhadap CVV p >0,05, akan tetapi mengkonsumsi/menggunakan antibiotik, multi- partner, higiene yang buruk, bilas vagina bermakna secara klinis berturut turut antibiotika (OR3,11; 95\% $\mathrm{Cl}$ 0,26-37,96), multipartner (OR 3,11; 95\% Cl 0,2637,96), higiene buruk (OR 6,33; 95\% $\mathrm{Cl} 0,36-110,5)$, bilas vagina (OR 1,36; 95\% $\mathrm{Cl} 0,25-7,49$. 
Tabel 8 Analisis bivariat hubungan variabel pengganggu dengan Trichomonas Vaginalis

\begin{tabular}{|c|c|c|c|c|c|c|c|}
\hline \multirow{3}{*}{ Variabel } & & \multicolumn{4}{|c|}{ Trichomonas Vaginalis } & \multirow{3}{*}{$\mathrm{p}$} & \multirow{3}{*}{ OR (Cl 95\%) } \\
\hline & & \multicolumn{2}{|c|}{ Ya } & \multicolumn{2}{|c|}{ Tidak } & & \\
\hline & & $\mathrm{n}$ & $\%$ & $\mathrm{n}$ & $\%$ & & \\
\hline \multirow[t]{2}{*}{ Usia } & $<20 />35$ & 3 & 100 & 35 & 53,8 & 0,249 & \\
\hline & $20-35$ & 0 & 0 & 30 & 46,2 & & \\
\hline \multirow[t]{2}{*}{ Paritas } & Multigravida & 3 & 100 & 43 & 66,2 & 0,546 & \\
\hline & Primigravida & 0 & 0 & 22 & 33,8 & & \\
\hline \multirow[t]{2}{*}{ Pendidikan } & Rendah & 2 & 66,7 & 23 & 35,4 & 0,550 & $3,65(0,31-42,5)$ \\
\hline & Tinggi & 1 & 33,3 & 42 & 64,6 & & \\
\hline \multirow[t]{2}{*}{ Pekerjaan } & Bekerja & 1 & 33,3 & 30 & 46,2 & 1,000 & $0,58(0,05-6,76)$ \\
\hline & Tidak & 2 & 66,7 & 35 & 53,8 & & \\
\hline \multirow[t]{2}{*}{ Antibiotika } & $\mathrm{Ya}$ & 1 & 33,3 & 2 & 3,1 & 0,128 & $15,8(0,97-254,6)$ \\
\hline & Tidak & 2 & 66,7 & 63 & 96,9 & & \\
\hline \multirow[t]{2}{*}{ Multipartner } & Ya & 1 & 33,3 & 2 & 3,1 & 0,128 & $15,8(0,97-254,6)$ \\
\hline & Tidak & 2 & 66,7 & 63 & 96,9 & & \\
\hline \multirow[t]{2}{*}{ Higiene buruk } & $\mathrm{Ya}$ & 1 & 33,3 & 1 & 1,5 & 0,087 & $32(1,43-716,5)$ \\
\hline & Tidak & 2 & 66,7 & 64 & 98,5 & & \\
\hline \multirow[t]{2}{*}{ Bilas vagina } & $\mathrm{Ya}$ & 1 & 33,3 & 10 & 15,4 & 0,416 & $2,75(0,23-33,28)$ \\
\hline & Tidak & 2 & 66,7 & 55 & 84,6 & & \\
\hline
\end{tabular}

Dari tabel di atas diketahui bahwa tidak terdapat hubungan bermakna secara statistik antara usia, paritas, pendidikan, pekerjaan, mengkonsumsi/ menggunakan antibiotik, multipartner, higiene yang buruk, bilas vagina terhadap TV $p>0,05$, sebaliknya variabel pengganggu seperti pendidikan, penggunaan antibiotika, multipartner, higiene yang buruk, bilas vagina bermakna secara klinis berturut turut pendidikan (OR 3,65; 95\% CI 0,3142,5) antibiotika (OR 15,8; 95\% CI 0,97-254,6), multipartner (OR 15,8; 95\% CI 0,97-254,6), higiene buruk (OR 32; 95\% CI 1,43-716,5), bilas vagina (OR 2,75; $95 \% C I 0,23-33,28$

Tabel 9. Analisis multivariat hubungan AKDR dan variabel pengganggu terhadap Vaginosis Bakteri

\begin{tabular}{llcc}
\hline \multicolumn{1}{c}{ Variabel } & & $\mathrm{p}$ & OR (CI 95\%) \\
\hline AKDR & Ya & $0,009 *$ & $\begin{array}{c}10,11(1,80- \\
56,78)\end{array}$ \\
& Tidak & & $0,52(0,10-$ \\
Usia & $<20 />35$ & 0,426 & $2,50)$ \\
& $20-35$ & & $1,84(0,37-9,5)$ \\
Paritas & Multigravida & 0,455 & \\
& Primigravida & &
\end{tabular}

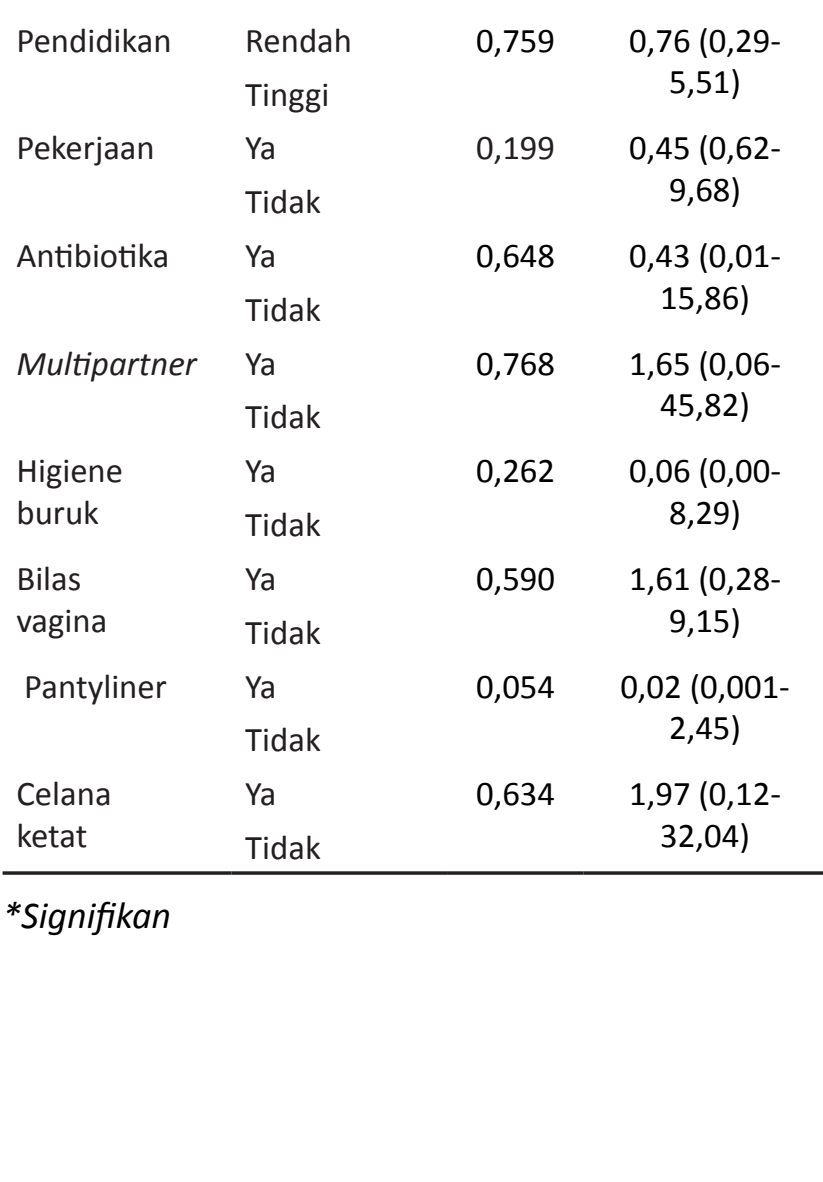


Tabel diatas menunjukkan bahwa AKDR berpengaruh terhadap VB $p=0,009(p<0,05)$ dengan nilai OR $10,11(1,80-56,78)$ yang berarti subjek akseptor AKDR non hormonal berpeluang mengalami VB 10,11 kali dibandingkan kontrasepsi hormonal. Terdapat empat variabel pengganggu tidak bermakna secara statistik tetapi bermakna secara klinis berturut turut paritas (OR 1,84;95\% CI0,37-9,5), multipartner (OR 1,$65 ; 95 \%$ CI 0,06-45,82), bilas vagina (OR 1,61; $95 \%$ CI 0,28-9,15), celana ketat (OR 1,97;95\% CI 0,12$32,04)$.

Tabel 10. Analisis multivariat hubungan AKDR non hormonal dan variabel pengganggu terhadap Candidiasis Vulvovagina

\begin{tabular}{|c|c|c|c|}
\hline Variabel & & $\mathrm{p}$ & OR (Cl 95\%) \\
\hline \multirow[t]{2}{*}{ AKDR } & Ya & $0,022^{*}$ & $29,78(1,64-2540,69)$ \\
\hline & Tidak & & \\
\hline \multirow[t]{2}{*}{ Usia } & $<20 />35$ & 0,635 & $0,540,04-6,94)$ \\
\hline & $20-35$ & & \\
\hline \multirow[t]{2}{*}{ Paritas } & Multigravida & 0,126 & $0,15(0,01-1,7)$ \\
\hline & Primigravida & & \\
\hline \multirow[t]{2}{*}{ Pendidikan } & Rendah & 0,388 & $0,24(0,01-5,91)$ \\
\hline & Tinggi & & \\
\hline \multirow[t]{2}{*}{ Pekerjaan } & Ya & 0,883 & $1,18(0,12-11,9)$ \\
\hline & Tidak & & \\
\hline \multirow[t]{2}{*}{ Antibiotika } & Ya & 0,703 & $0,46(0,008-25,11)$ \\
\hline & Tidak & & \\
\hline \multirow[t]{2}{*}{ Multipartner } & Ya & 0,188 & $15,92(0,26-985,45)$ \\
\hline & Tidak & & \\
\hline \multirow[t]{2}{*}{ Higiene buruk } & Ya & 0,205 & $33,94(0,15-7904,1)$ \\
\hline & Tidak & & \\
\hline \multirow[t]{2}{*}{ Bilas vagina } & Ya & 0,083 & $11,06(0,73-166,71)$ \\
\hline & Tidak & & \\
\hline \multirow[t]{2}{*}{ Pantyliner } & Ya & 0,291 & $0,16(0,005-4,91)$ \\
\hline & Tidak & & \\
\hline \multirow[t]{2}{*}{ Celana ketat } & Ya & 0,803 & $0,59(0,01-36,3)$ \\
\hline & Tidak & & \\
\hline
\end{tabular}

*Signifikan

Tabel diatas menunjukkan bahwa AKDR berpengaruh terhadap vaginitis yang disebabkan CVV $p=0,021(p<0,05)$ dengan nilai (OR 20,55; 95\% CI 1,58-267,3) yang berarti akseptor AKDR non hormonal berpeluang mengalami CVV 20,55 kali dibandingkan akseptor KB hormonal. Disisi lain variabel penganggu seperti pekerjaan, multipartner, higiene buruk, bilas vagina tidak bermakna secara statistik terhadap CVV $(p>0,05)$ tetapi bermakna secara klinis berturut turut (OR 1,18;95\% CI 0,1211,9), (OR 15,92;95\% CI 0,26-985,45), (OR 33,94; 95\% CI 0,15-7904,1), (OR 11,06; 95\% CI 0,73$166,71)$. 
Tabel 11. Analisis multivariat hubungan AKDR non hormonal dan variabel pengganggu terhadap Trichomonas Vaginalis

\begin{tabular}{|c|c|c|c|}
\hline Variabel & & $p$ & OR (Cl 95\%) \\
\hline \multirow[t]{2}{*}{ AKDR } & $\mathrm{Ya}$ & 0,460 & $3,68(0,11-117,63)$ \\
\hline & Tidak & & \\
\hline \multirow[t]{2}{*}{ Usia } & $<20 />35$ & 0,108 & $61,54(0,49-9381,15)$ \\
\hline & $20-35$ & & \\
\hline \multirow[t]{2}{*}{ Paritas } & Multigravida & 0,704 & $0,47(0,009-23,45)$ \\
\hline & Primigravida & & \\
\hline \multirow[t]{2}{*}{ Pendidikan } & Rendah & 0,411 & $0,19(0,004-9,89)$ \\
\hline & Tinggi & & \\
\hline \multirow[t]{2}{*}{ Pekerjaan } & $\mathrm{Ya}$ & 0,712 & $0,63(0,05-7,48)$ \\
\hline & Tidak & & \\
\hline \multirow[t]{2}{*}{ Antibiotika } & $\mathrm{Ya}$ & 0,071 & $47,80(0,72-3168,22)$ \\
\hline & Tidak & & \\
\hline \multirow[t]{2}{*}{ Multipartner } & $\mathrm{Ya}$ & 0,296 & $6,39(0,19-207,15)$ \\
\hline & Tidak & & \\
\hline \multirow[t]{2}{*}{ Higiene buruk } & $\mathrm{Ya}$ & 0,260 & $17,89(0,12-2718,24)$ \\
\hline & Tidak & & \\
\hline \multirow[t]{2}{*}{ Bilas vagina } & $\mathrm{Ya}$ & 0,785 & $0,61(0,01-21,28)$ \\
\hline & Tidak & & \\
\hline \multirow[t]{2}{*}{ Pantyliner } & $\mathrm{Ya}$ & 0,790 & $1,6(0,05-51,44)$ \\
\hline & Tidak & & \\
\hline \multirow[t]{2}{*}{ Celana ketat } & $\mathrm{Ya}$ & 0,182 & $15,2(0,28-828,33)$ \\
\hline & Tidak & & \\
\hline
\end{tabular}

Tabel diatas menunjukkan bahwa semua variabel tidak bermakna secara statistik terhadap TV $(p>0,05)$, akan tetapi terdapat variabel yang bermakna secara klinis berturut turut AKDR non hormonal (OR 3,68; 95\% CI 0,11-117,63), usia (OR 61,54;95\% CI 0,49-9381,15), mengkonsumsi/ menggunakan antibiotika (OR 47,80; 95\% CI 0,723168,22), multipartner (OR 6,39; 95\% CI 0,19207,15), higiene buruk (OR 17,89; 95\% CI 0,12$2718,24)$, celana ketat (OR 15,2;95\% CI0,28-828,33).

Pada penelitian ini didapatkan hasil bahwa motode kontrasepsi AKDR non hormonal bermakna secara statistik terhadap kejadian VB dan CVV $(p<0,05)$. Sementara itu AKDR non hormonal tidak bermakna secara statistik terhadap kejadian TV, akan tetapi bermakna secara klinis. Hasil ini hampir sama dengan penelitian sebelumnya. Thulkar (2010) yang meneliti etiologi vaginitis pada berbagai metode kontrasepsi menemukan bahwa AKDR merupakan metode kontrasepsi ke-4 terbanyak menyebabkan vaginitis setelah ligasi tuba, KB kalender, dan kondom. Dari penelitian ini juga didapatkan bahwa VB merupakan yang terbanyak $53,8 \%$, diikuti CVV $6,2 \%$, dan yang terakhir oleh karena TV $3,2 \%$.

Akseptor AKDR diperiksa menggunakan papsmear. Hasilnya, dari 286 pasien yang diteliti didapatkan vaginitis yang disebabkan oleh bakteri sebanyak $4,3 \%$ dan yang disebabkan oleh candida sebanyak 4,2\%. ${ }^{5}$ Hasil yang hampir sama juga didapatkan Al-Kattan yang menemukan 39 dari 42 AKDR yang terinfeksi berhubungan dengan infeksi vaginitis. ${ }^{9}$ Jabuk menemukan $64 \%$ hasil swab vagina akseptor KB AKDR terinfeksi bakteri. ${ }^{10}$

Dagli meneliti koloni servikovagina pada wanita yang aktif secara seksual dan menggunakan AKDR sebagai metode kontrasepsinya. Dagli mendapatkan hasil bahwa dari 96 sampel sekret vagina yang diteliti didapatkan 5 sampel $(5,2 \%)$ yang mengandung clue 
cell dan 7 sampel (7,3\%) mengandung Candida Sp, sedangkan Trichomonas tidak didapatkan pada seluruh sampel yang diperiksa. ${ }^{1}$

Hubungan penggunaan AKDR dengan kejadian TV pada penelitian ini didapatkan hasil yang tidak signifikan dimungkinkan karena secara insidensi kejadian TV lebih sedikit dibandingkan kejadian VB dan CVV. Hal ini diperkuat oleh penelitian Fosch et al yang berjudul perbedaan metode kontrasepsi pada mikrobiota vagina tidak didapatkan TV pada keseluruhan sampel yang memakai kontrasepsi AKDR. ${ }^{11}$

Penelitian ini juga mendapatkan bahwa mengkonsumsi/menggunakan antibiotik, multipartner, higiene yang buruk, bilas vagina tidak bermakna secara statistik terhadap kejadian VB, CVV, dan TV, akan tetapi bermakna secara klinis terhadap CVV dan TV, sehingga faktor-faktor pengganggu ini dimasukkan ke dalam analisis multivariat bersama AKDR dalam menyebabkan vaginitis. Dari analisis ini didapatkan bahwa paritas, multipartner, bilas vagina, dan pemakaian celana ketat merupakan faktor risiko terjadinya VB, sedangkan multipartner, hygiene buruk, dan bilas vagina merupakan faktor risiko terjadi nya CVV. Secara umum, Hasil dari analisis faktor pengganggu ini hampir sama dengan teori yg sudah ada sebelumnya, dimana disebutkan bahwa mengkonsumsi/menggunakan antibiotik, multipartner, higiene buruk, penggunaan bilas vagina $\mathrm{me}^{11,12}$

Faktor risiko terjadi nya TV dalam penelitian ini yaitu usia, antibiotik, hygiene buruk, pantyliner serta pemakaian celana ketat. Hasil penelitian ini berbanding terbalik dengan penelitian sebelumnya dimana secara teori, trichomonas termasuk infeksi menular seksual yang secara spesifik penularannya lebih ke arah hubungan seksual multipartner dibandingkan oleh karena metode kontrasepsi. ${ }^{11}$

\section{KESIMPULAN \& SARAN}

Penggunaan AKDR non hormonal meningkatkan kejadian Vaginitis Bakteri dibandingkan dengan kontrasepsi hormonal (OR 10,11;95\% CI 1,80$56,78)$, disisi lain AKDR non hormonal meningkatkan kejadian Candidiasis Vulvovagina dibandingkan kontrasepsi hormonal (OR 29,78;95\% CI 1,64$2540,69)$. Berlawanan dengan hal tersebut AKDR non hormonal tidak bermakna secara statistik sebagai penyebab Trichomonas Vaginalis tetapi bermakna secara klinis (OR 3,68;95\% CI 0,11-117,63).

Penelitian dengan jumlah sampel lebih besar juga dapat dilakukan untuk mengetahui hubungan AKDR terhadap kejadian Trichomonas Vaginalis dengan kekuatan penelitian $80 \%$.

\section{DAFTAR PUSTAKA}

1. Dagli SS, Demir T. 2015. Comparison of cervicovaginal colonization among sexually active women by intrauterine device use. I Infect Dev Ctries; 9(9):930-935

2. Aldunate $M$, Srbinovski $D$, Hearps $A C$, Latham $C F$, Ramsland PA, Gugasyan R et al. 2015. Antimicrobial and immune modulatory effects of lactic acid and short chain fatty acids produced by vaginal microbiota associated with eubiosis and bacterial vaginosis. Front. Physiol; 6:164

3. Petrova MI, Lievens E, Malik S, Imholz N, Lebeer S. 2015. Lactobacillus species as biomarkers and agents that can promote various aspects of vaginal health. Front. Physiol; 6(81):1-18

4. Thulkar J, Kriplani A, Agarwal N, Vishnubhatla S. 2010. Aetiology \& risk factors of recurrent vaginitis \& its association with various contraceptive methods. Indian J Med Res; 131: 83-87

5. Donders GG, Berger J, Heuninckx H, Bellen G, Cornelis A. 2011. Vaginal flora changes on Pap smears after insertion of levonorgestrel-releasing intrauterine device. Contraception; 83: 352-356

6. Buhling KJ, Zite NB, Lotke P, Black K. 2014. Worldwide use of intrauterine contraception: a review. Contraception. Elsevier; 89: 162-173

7. Callegari LS, Darney BG, Godfrey EM, Sementi O, MD, Dunsmoor-Su R, Prager SW. 2014. EvidenceBased Selection of Candidates for the Levonorgestrel Intrauterine Device (IUD). J Am Board Fam Med; 27(1): 26-33

8. Caddy S, Yudin MH, Hakim J, Money DM. 2014. Best Practices to Minimize Risk of Infection With Intrauterine Device Insertion. J Obstet Gynaecol Can; 36(3): 266-274

9. Al-Kattan SAA, Burhan DT, Burhan ST. 2013. Biofilm Formation on Intrauterine Device and Associated Infections.The Iraqi Postgraduate Medical Journal; 12(4):562-567

10. Jabuk SIA. 2014. Prevalence of aerobic bacterial vaginosis among Intrauterine Contraceptive Device users women in Hilla city. Journal of Babylon University; 22(9): 2424-2431

11. Fosch SE, Yones C, Trossero M, Grosso O. 2013. The influence of different contraceptive methods on vaginal microbiota: Clinical study. Health;5(7A4): 1924 
12. FSRH. 2012. Management of Vaginal Discharge in Genitourinary Medicine Settings. Faculty of Sexual and Reproductive Healthcare Clinical Guidance: 1-12
13. Mayo Clinic. 2014. Vaginitis. Mayo Foundation for Medical Education and Research: 1-7 